\title{
Lokus Kendali Internal dan Kemampuan Interpersonal sebagai Prediktor Kesiapan Mengelola Bisnis
}

\author{
Agung Minto Wahyu, ${ }^{1, *}$, Angga Yuni Mantara ${ }^{2}$, Rakhmaditya Dewi Noorrizki ${ }^{3}$ \\ ${ }^{1}$ Fakultas Pendidikan Psikologi, Universitas Negeri Malang, Malang, Indonesia \\ ${ }^{2}$ Fakultas Pendidikan Psikologi, Universitas Negeri Malang, Malang, Indonesia \\ ${ }^{3}$ Fakultas Pendidikan Psikologi, Universitas Negeri Malang, Malang, Indonesia \\ *Email: agungminto98@gmail.com
}

\begin{abstract}
Students' ability to operate their business will be determined by certain aspects. The aim of this study was to analyze the influence of internal locus of control (X1) and interpersonal ability (X2) on the readiness to manage business (Y). This research uses quantitative methods with linear regression analysis. Subjects were 141 business students. Sampling method that was used in this research was a purposive sampling technique using a Likert scale. Descriptive test results indicate that most students have internal locus of control, interpersonal skills, and readiness to manage businesses that are in the medium category. Partial test shows that X1 has a positive and significant effect on readiness to manage business Y. Variable X2 has a positive and significant effect on $Y$. Simultaneous results show that X1 and X2 have positive and significant effects on $Y$. In next research researchers are expected to be able to broaden the scope of the subject and explore further about the independent variables that have the ability to influence the readiness to manage the business. More detailed discussions and suggestions have been discussed in this study.
\end{abstract}

Abstraksi: Kemampuan mahasiswa dalam mengelola bisnisnya akan dipengaruhi oleh aspek-aspek tertentu. Penelitian ini berupaya untuk mengetahui tingkat pengaruh lokus kendali internal (X1) serta kemampuan interpersonal (X2) terhadap kesiapan mengelola bisnis (Y). Peneliti menggunakan pendekatan metode kuantitatif dengan analisis regresi linear. Subjek penelitian ini melibatkan 141 mahasiswa pelaku bisnis. Sampling dilakukan dengan teknik purposive sampling dengan menggunakan jenis skala likert. Hasil uji deskriptif menunjukkan bahwa sebagian besar mahasiswa memiliki lokus kendali internal, kemampuan interpersonal, dan kesiapan mengelola bisnis yang berada pada kategori sedang. Uji parsial menunjukkan bahwa lokus kendali internal berpengaruh positif dan signifikan terhadap kesiapan mengelola bisnis. Selain itu Kemampuan interpersonal berpengaruh positif dan signifikan terhadap kesiapan mengelola bisnis. Uji simultan menunjukkan bahwa X1 dan X2 berpengaruh positif dan signifikan terhadap Y. Saran bagi peneliti selanjutnya, diharapkan agar dapat memperluas cakupan dari subjek serta mengeksplorasi lebih jauh mengenai variabel bebas yang memiliki kemampuan untuk mempengaruhi kesiapan mengelola bisnis. Pembahasan dan saran lebih rinci telah dibahas di dalam penelitian ini.

Keywords: internal locus of control; interpersonal ability; readiness; student business

\section{Pendahuluan}

Mahasiswa diharapkan mampu membawa perubahan, karena mahasiswa dianggap sebagai agent of change untuk membuat Indonesia lebih baik. Salah satu upaya yang dilakukan ialah menjadi wirausahawan. Jack Ma (dalam Rosmayanti, 2018) menjelaskan ada tiga E yang berperan penting untuk kemajuan ekonomi suatu negara saat ini. Tiga E yang dimaksud ialah entrepreneurship (kewirausahaan), education (pendidikan), dan e-government (manajemen pemerintahan berbasis teknologi). Namun data dari Badan Pusat Statistik (2016) menunjukkan bahwa jumlah wirausahawan di Indonesia hanya berkisar 3,10 persen dari jumlah penduduk Indonesia.
Pemerintah tentunya tidak tinggal diam. Melalui Badan Ekonomi Kreatif (Bekraf) yang memiliki tugas untuk meringankan beban kerja presiden dengan membantunya dalam merumuskan, mengoordinasikan, menetapkan, dan melakukan sinkronisasi terhadap kebijakan yang berkaitan dengan ekonomi kreatif. Dengan tugas seperti itu, Bekraf diharapkan dapat menciptakan lingkungan ekonomi kreatif yang kondusif. Hal ini juga dikarenakan sumbangsih ekonomi kreatif terhadap total perekonomian nasional tahun 2016 cukup besar, yakni 7,44\% atau sekitar 922,59 triliun rupiah (Bekraf, 2017).

Bekraf Youth Technology Entrepreneurs (BYTE) sebagai program yang diinisiasi oleh Bekraf diharapkan mampu membuat mahasiswa tertarik dengan menjadi bagian 
dari industri kreatif. Hal ini dikarenakan kebanyakan mahasiswa sebagai bagian dari generasi $\mathrm{Z}$ dan alpha yang memiliki penguasaan teknologi informasi lebih baik dibandingkan generasi sebelumnya. Sehingga diharapkan proses mendapat informasi dari berbagai sumber yang lebih mudah untuk generasi ini berpikiran kreatif dan inovatif. Terlebih lagi, ide kreatif akan bernilai lebih tinggi apabila dapat dimanifestasikan dalam bentuk nyata (Bekraf, 2017)

Pada kenyataannya, kreatif dan inovatif membangun dalam sebuah ide tidak cukup bagi mahasiswa untuk membentuk sebuah bisnis, khususnya bisnis yang sifatnya berkelanjutan. Mahasiswa diharapkan memiliki kesiapan yang baik sebelum mendirikan bisnis agar tetap dapat beroperasi. Diperlukan kesiapan dari pelaku industri untuk memulai usahanya. Kesiapan (readiness) ialah kondisi menyeluruh dari individu untuk memberikan respon terhadap situasi yang dihadapi (Slameto, 2015). Dalam konteks wirausahawan adalah kesiapannya menghadapi tantangan ke depan, semakin siap ia, maka semakin baik pula respon yang diberikan. Salah satu hal yang dapat mempengaruhi kesiapan ialah dari faktor internal masing-masing individu, terlebih lagi ialah locus of control (Rauch \& Frese, 2007; Adnyana \& Purnami, 2016).

Reiss dan Mitra

mengklasifikasikan locus of control menjadi dua, yaitu internal dan external locus of control. Lokus kendali internal adalah cara individu dalam menggunakan sudut pandang dimana segala hasil yang dicapai baik positif maupun negatif disebabkan karena tindakan yang merupakan faktor-faktor dari individu itu sendiri. External locus of control adalah sudut pandang bahwa segala hasil yang telah dicapai baik positif maupun negatif disebabkan bukan karena kontrol dalam diri, melainkan dipengaruhi oleh faktor dari luar seperti kesempatan, keberuntungan, atau bahkan dianggap sebagai suratan takdir. Diantara keduanya, locus of control yang berpengaruh dalam minat kewirausahaan, atau bahkan keberhasilannya adalah lokus kendali internal (Parsa, 2011).

Kemampuan interpersonal turut mempengaruhi bagaimana individu menjalankan usaha. Porter et al., (1999) mendefinisikan kemampuan interpersonal adalah kemampuan dalam mengelola diri yang dilakukan secara efektif ketika berkolaborasi dengan individu lain untuk menyelesaikan pekerjaan secara bersama. Kemampuan interpersonal sangat dibutuhkan apabila dikaitkan dengan usaha untuk menjalin relasi bisnis. Beberapa faktor yang turut mempengaruhi kemampuan interpersonal seseorang ialah gabungan dari keturunan, sosial, dan pengalaman hidup (Gunawan, 2011).

Gabungan dari kedua unsur variabel yaitu lokus kendali internal dan kemampuan interpersonal dapat membentuk kesiapan yang baik untuk mengelola bisnis pada mahasiswa. Thorndike (dalam Rahyubi, 2012) menyampaikan hukum kesiapan (Law of Readiness) yang berbunyi bahwa semakin siap suatu individu dalam melakukan suatu perubahan tingkah laku, maka setiap pelaksanaan tingkah laku akan menimbulkan kepuasan individu sehingga asosiasi akan cenderung diperkuat. Oleh sebab itu, apabila seseorang semakin siap untuk melakukan atau menerima sesuatu yang dihadapi maka akan semakin baik hasil yang diperoleh sehingga besar kemungkinan untuk mendapatkan rasa kepuasan dari apa yang telah dilakukannya.

Beberapa penelitian terdahulu yang menggunakan variabel lokus kendali internal terhadap intensi dan minat berwirausaha dilakukan oleh Adnyana dan Purnami (2016), Endratno dan Widhiandono (2017), Musdalifah dan Baharuddin (2016), Nizma dan Siregar (2018), Srimulyani (2013). Hasil penelitian tersebut sebagian besar menyatakan berpengaruh secara positif dan signifikan. Akan tetapi, dari keseluruhan penelitian tersebut belum ada yang secara langsung menggunakan variabel terikat yaitu kesiapan mengelola bisnis pada mahasiswa. Sejauh ini, hanya Fauzan (2019) yang melakukan penelitian dengan variabel lokus kendali internal terhadap kesiapan fresh graduate dalam era industri 4.0 dan penelitian Kholifah dan Hadi (2017). Kedua hasil penelitian tersebut menyatakan bahwa terdapat pengaruh positif yang signifikan.

Penelitian terdahulu mengenai variabel kemampuan interpersonal terhadap kesiapan 
mengelola bisnis pada mahasiswa masih belum banyak. Sejauh ini hanya ada penelitian Rahmin (2018) yang hasil penelitiannya yaitu kemampuan interpersonal berpengaruh positif yang signifikan terhadap keputusan berwirausaha pada Masyarakat Kota Makassar. Belum ada penelitian yang mengaitkan antara variabel kemampuan interpersonal terhadap kesiapan mengelola bisnis pada mahasiswa. Selain itu, subjek penelitian Rahmin (2018) adalah masyarakat umum. Belum ada yang menggunakan subjek mahasiswa dalam penelitian terkait hal ini.

Berdasarkan uraian tersebut, maka peneliti memiliki ketertarikan untuk melakukan penelitian yang berjudul pengaruh lokus kendali internal dan kemampuan interpersonal terhadap kesiapan mengelola bisnis pada mahasiswa. Adapun tujuan penelitian ini yakni untuk mengetahui pengaruh dari lokus kendali internal dan kemampuan interpersonal terhadap kesiapan mengelola bisnis pada mahasiswa.

\section{Kajian Teori}

\section{Lokus Kendali Internal}

Lokus kendali internal didefinisikan oleh Martin dan Lefcourt (1983) sebagai suatu keyakinan bahwa segala hasil yang dicapai merupakan hasil dari usaha yang telah dilakukannya sendiri, bukan berasal dari faktor-faktor eksternal. Definisi yang sama dipaparkan oleh Reiss dan Mitra (1998), lokus kendali internal merupakan keyakinan bahwa segala hasil yang diperoleh, baik yang bersifat positif atau negatif adalah hasil dari tindakan kapasitas dan faktor-faktor dalam diri mereka sendiri. Lokus kendali internal sering diasosiasikan dengan usaha aktif untuk mencapai sebuah target yang telah ditetapkan, pengejawantahannya berupa tindakan untuk mencari informasi, tindakan sosial, serta otonomi dalam mengambil keputusan (Levenson, 1973). Individu akan lebih gigih dan percaya diri dalam menjalani kehidupannya, apabila individu tersebut memiliki keyakinan bahwa segala sesuatu yang terjadi dalam kehidupannya tersebut ditentukan oleh tindakannya sendiri. Sebaliknya, individu yang memiliki keyakinan bahwa kehidupan yang dijalaninya adalah hasil kontrol dari kekuatan eksternal, maka kecenderungannya adalah individu tersebut akan sering merasa tertekan dan tidak berdaya (Myers, 1983). Davis dan Phares (1969) memaparkan bahwa individu yang memiliki keyakinan internal yang tingi akan cenderung lebih mampu berperilaku optimis dan percaya diri dalam memutuskan setiap permasalahan yang dihadapinya. Karakteristik secara rinci mengenai lokus kendali internal disampaikan oleh Ghufron (2010) dan Crider (1983) yaitu, cenderung ingin berhasil dalam setiap usahanya, pantang menyerah dalam memecahkan permasalahan, pekerja keras, inisiatif dan berpikir secara efektif.

Davis dan Phares (1969) memaparkan bahwa lokus kendali internal memiliki tiga aspek pembentuk, yaitu 1) Kemampuan, yang diartikan sebagai potensi untuk memiliki atau menguasai sebuah keahlian (Kartono dan Gulo, 2000). 2) Minat, yang diartikan sebagai kombinasi antara kemauan dan keinginan yang dapat terus dikembangkan selama diiringi dengan motivasi yang tinggi (Tampubolon, 2004). 3) Usaha, maksudnya adalah sebuah bentuk usaha maksimal yang dilakukan oleh individu yang bersikap pantang menyerah dan optimis sehingga dapat mengontrol perilaku yang sedang dilakukannya tersebut.

\section{Kemampuan Interpersonal}

Porter et al., (1999) mendefinisikan kemampuan interpersonal adalah kemampuan dalam mengelola diri yang dilakukan secara efektif ketika berkolaborasi dengan individu lain untuk menyelesaikan pekerjaan secara bersama. Ketika menjalin hubungan bisnis dengan pihak lain tentu akan sangat membutuhkan kemampuan interpersonal yang baik. Kemampuan interpersonal juga diartikan sebagai kemampuan dalam melakukan pekerjaan dengan orang lain (Handfield, 2006). Barrington (2004) memaparkan bahwa kecerdasan interpersonal adalah kemampuan untuk merespons, memahami dan menjalin hubungan baik dengan orang lain. Kemampuan interpersonal juga didefinisikan sebagai kemampuan yang relevan untuk digunakan dalam menjalin relasi dan bekerjasama (McGaha dan Fitzpatrick, 2005). Kemampuan berkomunikasi interpersonal yang baik tersebut akan membantu memudahkan aktivitas yang sedang dilakukan oleh seseorang berdasarkan target yang telah 
ditetapkan sebelumnya (Gumay dan Seno, 2018).

Aspek-aspek yang membangun kemampuan interpersonal sendiri menurut Idrus (2009) yakni kemampuan menyelesaikan konflik dengan orang lain, kemampuan untuk membuka diri, asertif, kemampuan dalam memulai sebuah pembicaraan, kemampuan dalam memberikan dukungan emosional dan empati.

\section{Kesiapan (Readines) Mengelola Bisnis}

Kesiapan mengelola bisnis merupakan kondisi ketika individu telah mempunyai bekal yang cukup untuk menjalankan bisnisnya sehingga lebih siap dalam menghadapi berbagai permasalahan bisnis yang dijalani. Situasi tersebut membutuhkan kesiapan fisik dan mental untuk memberikan respon yang sesuai dengan kondisi atau situasi yang sedang dihadapinya (Ratumbuysang \& Rasyid, 2015). Kesiapan (readiness) menurut Slameto (2015) adalah kondisi akumulatif yang dapat membuat individu siap dalam merespon setiap situasi dengan cara atau strategi tertentu. Kesiapan (readiness) merupakan kesediaan individu dalam mengerjakan sesuatu dengan optimal (Soemanto, 2012). Dari perspektif lain, kesiapan seseorang ditentukan oleh kesiapan yang cukup dari segi fisik, mental, dan dukungan fasilitas untuk belajar dan berlatih (Dalyono, 2015). Individu yang memiliki kesiapan fisik biasanya akan terlihat dari kesehatannya yang prima dan didukung dengan tenaga yang baik. Di sisi lain, kesiapan mental dapat dilihat ketika individu memiliki minat dan motivasi yang tinggi untuk mengerjakan sebuah aktivitas. Dapat disimpulkan bahwa kesiapan (readiness) adalah kesiapan cukup yang berkaitan dengan mental, fisik, serta fasilitas pendukung untuk berlatih dan belajar sehingga membuatnya semakin siap untuk merespon secara baik dan tepat dalam cara tertentu terhadap segala situasi.

Interaksi dari keseluruhan aspek perkembangan yang saling memengaruhi merupakan prinsip dari kesiapan (readiness). Maka dari itu, rohani dan jasmani yang lebih matang akan berfungsi untuk memperoleh manfaat yang lebih banyak dari setiap pengalaman yang didapat. Sebab kesiapan akan dipengaruhi juga oleh pengalamanpengalaman sebelumnya. Kesiapan tidak hanya berupa kesiapan fisik saja, melainkan juga kesiapan dalam bentuk yang lain. Slameto (2015) menjelaskan aspek-aspek kesiapan, yakni kesiapan mental, kesiapan emosional, kesiapan fisik, memiliki tujuan, motif, kebutuhan, keterampilan, dan pengetahuan.

\section{Pengembangan Hipotesis}

Lokus kendali internal merupakan suatu keyakinan bahwa keseluruhan hasil yang dicapai adalah hasil dari kerja keras yang telah dilakukannya sendiri, bukan berasal dari faktor-faktor eksternal (Martin dan Lefcourt, 1983). Lokus kendali internal yang menjadi keyakinan dari mahasiswa akan berdampak pada kesiapannya dalam mengelola bisnis. Sebab menurut Slameto (2010), salah satu faktor pendorong kesiapan seseorang tergantung pada tinggi atau rendah keyakinannya dalam melakukan suatu hal tertentu. Maka dari itu, seseorang yang mempunyai lokus kendali internal yang tinggi akan cenderung sangat yakin dengan semua kemampuan yang dimilikinya (Davis dan Phares, 1969). Selain itu, penelitian dari (Endratno dan Widhiandono, 2017; Fauzan, 2019; Musdalifah dan Baharuddin, 2016; Srimulyani, 2013) juga menyatakan bahwa locus of control mampu menjadi prediktor positif yang signifikan terhadap kesiapan, intensi, maupun niat berwirausaha pada mahasiswa. Berdasarkan paparan tersebut, maka penulis merumuskan hipotesis 1a sebagai berikut: $\mathrm{H}_{1 \mathrm{a}}$ : Lokus kendali internal (X1) berpengaruh positif dan signifikan terhadap kesiapan mengelola bisnis $(\mathrm{Y})$

Kemampuan individu untuk melakukan pekerjaan bersama dengan orang lain merupakan kemampuan interpersonal (Hanfield, 2006). Melakukan pekerjaan bersama dengan orang lain adalah salah satu modal utama bagi seseorang dalam menjalankan bisnisnya. Dengan semakin tingginya kemampuan interpersonal tersebut, maka akan sangat berguna bagi mahasiswa dalam membentuk kesiapannya dalam mengelola bisnisnya. Dalam aspek-aspek yang disampaikan Slameto (2010) mengenai kesiapan adalah salah satunya yaitu kesiapan keterampilan. Keterampilan tersebut dapat 
berupa keterampilan berkomunikasi dengan orang lain. Berdasarkan hasil penelitian Iksanudin (20120, Rahmin (20180, Yuniati (2017), kemampuan interpersonal memiliki kemampuan positif untuk menjadi prediktor yang signifikan terhadap intensi, keputusan, dan kesiapan untuk melakukan pekerjaan bisnis pada mahasiswa. Berdasarkan paparan tersebut, maka dirumuskan hipotesis $1 \mathrm{~b}$ sebagai berikut: $\mathrm{H}_{1 \mathrm{~b}}$ : Kemampuan interpersonal (X2) berpengaruh positif dan signifikan terhadap kesiapan mengelola bisnis (Y).

Kesiapan mengelola bisnis merupakan sebuah kondisi ketika individu telah mempunyai bekal yang cukup untuk menjalankan bisnisnya sehingga lebih siap dalam menghadapi berbagai permasalahan bisnisnya secara positif dan signifikan. Berdasarkan paparan tersebut, maka dirumuskan hipotesis 1 sebagai berikut: $\mathrm{H}_{1}$ : Lokus kendali internal (X1) dan kemampuan interpersonal (X2) berpengaruh positif dan signifikan terhadap kesiapan mengelola bisnis (Y).

\section{Kerangka Konseptual}

Kajian-kajian literatur yang telah diuraikan sebelumnya tersebut menjadi dasar dalam menyusun kerangka konseptual dalam penelitian ini. Kerangka konseptual tersebut terdiri dari dua variabel bebas, yaitu lokus kendali internal (X1), kemampuan interpersonal (X2) dan satu variabel terikat, yakni kesiapan mengelola bisnis pada mahasiswa (Y). Berikut adalah ilustrasinya.

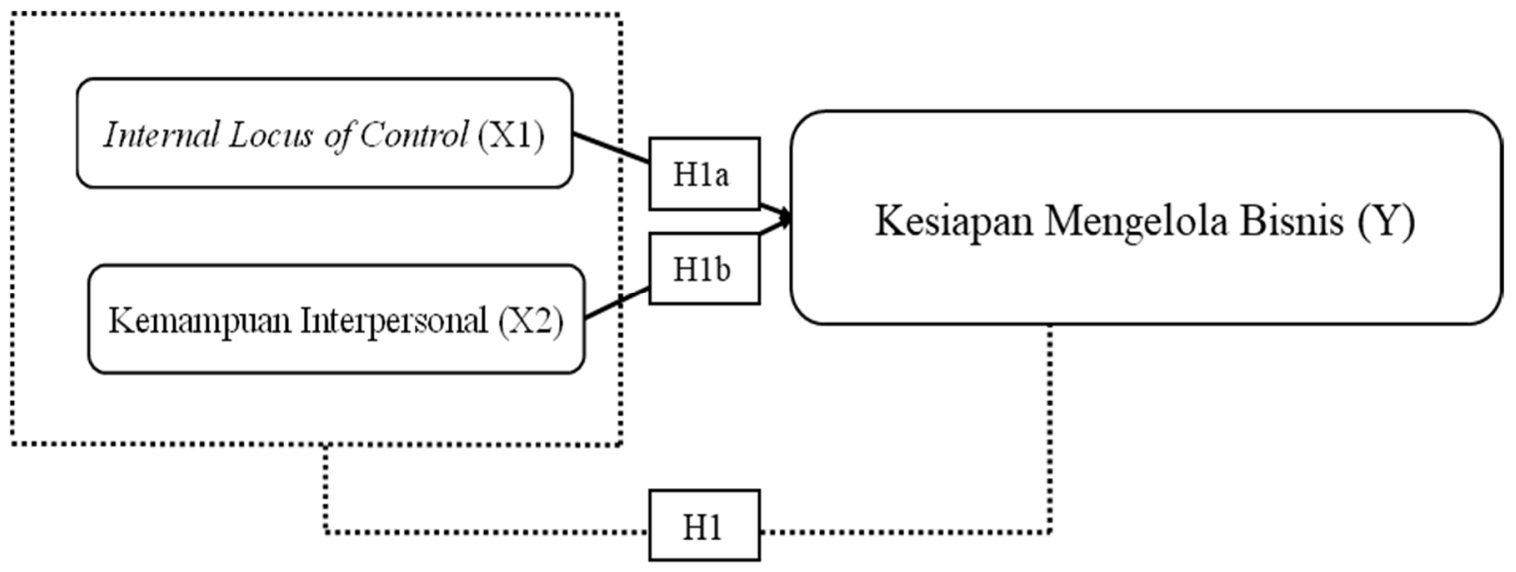

Gambar 1 Kerangka Konseptual

bisnis yang dijalani. Bekal tersebut diantaranya dapat berupa bekal secara fisik maupun non fisik (Ratumbuysang \& Rasyid, 2015). Di sisi lain, lokus kendali internal yang merupakan suatu keyakinan bahwa segala hasil yang dicapai merupakan hasil dari usaha yang telah dilakukannya sendiri, bukan berasal dari faktor-faktor eksternal tentu dapat bermanfaat untuk mempersiapkan diri dalam mengelola bisnis (Martin dan Lefcourt, 1983). Keyakinan terhadap diri sendiri yang telah diukur dengan variabel lokus kendali internal akan sangat berguna ketika dilengkapi dengan kemampuan interpersonal yang baik (Wahyu et al., 2019). Penelitian Susyanti \& Wahyu (2019) menunjukkan bahwa lokus kendali internal dan kompetensi interpersonal memiliki kemampuan untuk mempengaruhi kesiapan mahasiswa dalam mengelola

\section{Metode}

Metode yang digunakan dalam penelitian ini yaitu kuantitatif korelasional untuk mengetahui pengaruh variabel lokus kendali internal (X1) dan kemampuan interpersonal (X2) terhadap variabel kesiapan mengelola bisnis (Y). Populasi penelitian adalah Mahasiswa Malang yang berkuliah di salah satu Perguruan Tinggi Swasta (PTS). Teknik sampling menggunakan teknik purposive sampling dengan kriteria mahasiswa aktif salah satu PTS di Malang, dan memiliki bisnis yang berjalan minimal 1 tahun. Jumlah sampel yang terpilih berjumlah 141 responden.

Tiga instrumen skala yang digunakan dalam mengumpulkan data, yakni skala lokus kendali internal, skala kemampuan interpersonal, dan skala kesiapan mengelola 
bisnis. Skala lokus kendali internal dikonstruksi dari aspek-aspek milik Davis dan Phares (1969), yang terdiri dari kemampuan, minat, dan usaha. Skala kemampuan interpersonal dikonstruksi dari aspek-aspek milik Idrus (2009), yang terdiri dari aspek kemampuan menyelesaikan konflik dengan orang lain, kemampuan untuk membuka diri, asertif, kemampuan dalam memulai sebuah pembicaraan, kemampuan dalam memberikan dukungan emosional dan empati. Skala kesiapan mengelola bisnis dikonstruksi dari aspek-aspek milik Slameto (2015), yakni kesiapan mental, kesiapan emosional, kesiapan fisik, memiliki tujuan, memiliki motif, memiliki kebutuhan, memiliki keterampilan, dan memiliki pengetahuan.

Data penelitian yang telah diperoleh dari instrumen yang telah valid dan reliabel kemudian diuji asumsi klasik yang terdiri dari normalitas, linearitas, dan heteroskedastisitas. Selanjutnya analisis regresi linear sederhana dan regresi linear berganda dilakukan untuk menguji hipotesis penelitian. Analisis data dilakukan dengan bantuan IBM SPSS versi 25,0 untuk uji instrumen dan E-Views versi 9,0 untuk uji prasyarat dengan asumsi klasik serta uji hipotesis.

\section{Hasil}

\section{Uji Instrumen}

Hasil korelasi pada masing-masing skor item dengan skor item total digunakan untuk menentukan uji validitas instrumen. Hasil korelasi tersebut berperan sebagai nilai $r$ Hitung yang kemudian dikomparasikan dengan nilai $r$ Tabel. Item dalam skala akan dianggap valid apabila nilai $r$ Hitung $>$ nilai $r$ Tabel. Sebaliknya, Item dalam skala akan dianggap tidak valid apabila nilai $r$ Hitung $<$ nilai $r$ Tabel. Item-item yang valid tersebut kemudian dipergunakan dalam instrumen penelitian ini untuk mengukur masing-masing variabel. Berdasarkan hasil pengujian, pada variabel lokus kendali internal diperoleh 8 item valid yang telah mewakili keseluruhan aspek dalam variabel tersebut. Pada variabel kemampuan interpersonal, terdapat 13 item valid yang telah mewakili keseluruhan aspek pada variabel tersebut. Pada variabel kesiapan mengelola bisnis, diperoleh 16 item valid yang telah mewakili kedelapan aspek dari variabel tersebut.
Tabel 1. Hasil Uji Deskriptif

\begin{tabular}{|c|c|c|c|c|}
\hline $\begin{array}{c}\text { Variabel/ } \\
\text { Aspek }\end{array}$ & $\underset{\text { Item }}{\sum}$ & Mean & $\begin{array}{l}\text { Std. } \\
\text { Dev. }\end{array}$ & $\mathbf{N}$ \\
\hline $\begin{array}{c}\text { Lokus } \\
\text { Kendali } \\
\text { Internal (X1) }\end{array}$ & 8 & 27,55 & 2,57 & 141 \\
\hline $\begin{array}{l}\text { Kemampuan } \\
\text { (X1.1) }\end{array}$ & 2 & 3,20 & 0,40 & 141 \\
\hline Minat (X1.2) & 3 & 3,56 & 0,39 & 141 \\
\hline Usaha (X1.3) & 3 & 3,48 & 0,38 & 141 \\
\hline $\begin{array}{c}\text { Kemampuan } \\
\text { Interpersonal } \\
\text { (X2) }\end{array}$ & 13 & 43,90 & 4,06 & 141 \\
\hline $\begin{array}{l}\text { Memulai Suatu } \\
\text { Hubungan } \\
\text { (X2.1) }\end{array}$ & 3 & 3,24 & 0,41 & 141 \\
\hline $\begin{array}{l}\text { Kemampuan } \\
\text { Membuka Diri } \\
(\mathrm{X} 2.2)\end{array}$ & 3 & 3,51 & 0,44 & 141 \\
\hline Asertif (X2.3) & 1 & 3,28 & 0,57 & 141 \\
\hline Empati (X2.4) & 2 & 3,30 & 0,58 & 141 \\
\hline $\begin{array}{l}\text { Mengatasi } \\
\text { Konflik (X2.5) }\end{array}$ & 2 & 3,41 & 0,45 & 141 \\
\hline $\begin{array}{l}\text { Memberikan } \\
\text { Dukungan } \\
(\mathrm{X} 2.6) \\
\end{array}$ & 2 & 3,47 & 0,46 & 141 \\
\hline $\begin{array}{c}\text { Kesiapan } \\
\text { Mengelola } \\
\text { Bisnis (Y) } \\
\end{array}$ & 16 & 52,08 & 5,47 & 141 \\
\hline $\begin{array}{l}\text { Kesiapan Fisik } \\
\text { (Y.1) }\end{array}$ & 1 & 3,24 & 0,61 & 141 \\
\hline $\begin{array}{l}\text { Kesiapan } \\
\text { Mental (Y.2) }\end{array}$ & 1 & 2,98 & 0,67 & 141 \\
\hline $\begin{array}{l}\text { Kesiapan } \\
\text { Emosional } \\
(\mathrm{Y} .3) \\
\end{array}$ & 2 & 3,24 & 0,45 & 141 \\
\hline $\begin{array}{l}\text { Memiliki } \\
\text { Kebutuhan } \\
(Y .4)\end{array}$ & 2 & 3,27 & 0,59 & 141 \\
\hline $\begin{array}{l}\text { Memiliki } \\
\text { Motif (Y.5) }\end{array}$ & 2 & 3,46 & 0,39 & 141 \\
\hline $\begin{array}{l}\text { Memiliki } \\
\text { Tujuan (Y.6) }\end{array}$ & 3 & 3,50 & 0,43 & 141 \\
\hline $\begin{array}{l}\text { Memiliki } \\
\text { Keterampilan } \\
(\text { Y.7) }\end{array}$ & 3 & 3,17 & 0,48 & 141 \\
\hline $\begin{array}{l}\text { Memiliki } \\
\text { Pengetahuan } \\
(Y .8) \\
\end{array}$ & 2 & 2,95 & 0,47 & 141 \\
\hline
\end{tabular}

Sumber: Hasil analisis data, diolah (2020)

Alpha cronbach adalah jenis pengujian yang digunakan untuk mengetahui reliabilitas dari instrumen yang digunakan dalam penelitian ini. Uji reliabilitas ini dilakukan dengan menggunakan item-item yang 
sebelumnya sudah valid. Uji ini berguna untuk mengetahui konsistensi instrumen ini ketika digunakan dalam proses pengukuran. Berdasarkan kriteria reliabilitas milik Guilford (1985), hasil uji reliabilitas instrumen menunjukkan bahwa pada variabel lokus kendali internal dan variabel kemampuan interpersonal memiliki reliabilitas yang tinggi. Variabel kesiapan mengelola bisnis memiliki reliabilitas yang sangat tinggi.

\section{Analisis Deskriptif}

Sebelum memasuki bagian uji prasyarat dengan asumsi klasik serta uji hipotesis. Berikut adalah pemaparan hasil analisis deskriptif yang terdapat dalam penelitian.

Berdasarkan tabel 1, jumlah responden keseluruhan adalah 141 mahasiswa. Pada variabel lokus kendali internal (X1), mean total skor 27,55, dan standar deviasi 2,57. Pada variabel kemampuan interpersonal (X1), mean total skor 43,9, dan standar deviasi 4,06. Pada variabel kesiapan mengelola bisnis (X1), mean total skor sebesar 52,08, dan standar deviasi sebesar 5,47.

\section{Uji Asumsi Klasik}

Uji normalitas residual menggunakan komparasi dari nilai Probabilitas Jarque-Bera (JB) dengan nilai alpha. Jika probabilitas JB > 0,05 , maka residual data berdistribusi normal. Jika probabilitas $\mathrm{JB}<0,05$ maka residual data berdistribusi tidak normal (Mardani, 2017). Diketahui hasil dari Probabilitas JB sebesar 0,566 atau lebih dari 0,05. Maka dapat disimpulkan bahwa data penelitian ini berdistribusi normal.

Uji multikolinearitas adalah uji asumsi klasik yang terpenting dalam analisis regresi sebab menjadi independensi error di antara setiap pasangan kasus. Pelanggaran dalam asumsi ini dalam mengakibatkan masalah serius bagi validitas inferensi dari penggunaan F-statistics dalam analisis varian. Pedoman untuk mengetahui suatu model regresi yang bebas multikolinearitas yaitu ketika nilai Variance Inflation Factors (VIF) berada di antara angka 1 hingga 4. (Hays dan Winkler, 1975). Dari hasil uji multikolinearitas, diketahui bahwa nilai VIF masing-masing variabel berada di antara angka 1 hingga 4. Rinciannya yaitu variabel Lokus kendali internal dan variabel kemampuan interpersonal masing-masing sebesar 1,232. Dengan demikian, dapat disimpulkan bahwa pada masing-masing variabel bebas tersebut tidak terjadi multikolinearitas. Alasan penggunaan Centered VIF karena model pada penelitian ini menggunakan constant.

Pengujian heteroskedastisitas dilakukan dengan menggunakan metode BreuschPagan-Godfrey. Keputusan terjadi atau tidaknya heteroskedastisitas metode BreuschPagan-Godfrey pada model regresi linear adalah dengan melihat nilai Probabilitas ChiSquare (1) Obs*R-squared. Jika nilai Probabilitas Chi-Square (1) Obs*R-squared $>$ tingkat alpha 0,05 (5 persen), maka tidak terjadi heteroskedastisitas. Sebaliknya, Apabila nilai Probabilitas Chi-Square (1) Obs*R-squared < tingkat alpha 0,05 (5 persen), maka terjadi permasalahan heteroskedastisitas. Berdasarkan hasil pengujian, nilai Probabilitas Chi-Square (1) Obs*R-squared diperoleh sebesar $0,8339>$ alpha sebesar 0,05. Maka dari itu dapat diambil kesimpulan bahwa tidak terdapat masalah heteroskedastisitas pada variabelvariabel dalam penelitian ini.

\section{Uji Hipotesis Pengaruh X1 terhadap Y}

Tabel 2. Hasil Uji Regresi Variabel X1 terhadap Y

\begin{tabular}{ccccc}
\hline Var & Coeff & t-Stat & Prob. & $\mathbf{R}^{\mathbf{2}}$ \\
\hline $\mathrm{C}$ & 24.5603 & 5.58026 & \multirow{2}{*}{0.0000} & 0.22097 \\
$\mathrm{X} 1$ & 0.99896 & 6.27920 & & \\
\hline
\end{tabular}

Sumber: Hasil analisis data, diolah (2020)

Dari hasil $\mathrm{t}$ tabel menunjukkan bahwa $\mathrm{t}$ uji $>\mathrm{t}$ tabel $(6,279>1,65573)$ dan nilai signifikansinya sebesar 0,0000 , maka dapat diinterpretasikan bahwa $\mathrm{H} 1$ diterima sehingga terdapat pengaruh positif signifikan lokus kendali internal terhadap kesiapan mengelola bisnis. Semakin tinggi lokus kendali internal yang dimiliki oleh mahasiswa, maka akan semakin meningkatkan kesiapannya dalam mengelola bisnisnya.

Nilai $R$-squared menunjukkan tingkat kontribusi variabel bebas sebagai prediktor bagi variabel terikat. Nilai R-square variabel bebas sebesar 0,221, yang berarti bahwa variabel lokus kendali internal memiliki kemampuan sebesar 22,1 persen dalam mempengaruhi variabel kesiapan dalam 
mengelola bisnis. Sisanya sebesar 77,9 persen dipengaruhi oleh prediktor lain.

\section{Uji Hipotesis Pengaruh Variabel X2} terhadap $Y$

\section{Tabel 3. Hasil Uji Regresi Variabel X2 terhadap Y}

\begin{tabular}{ccccc}
\hline Var & Coeff & t-Stat & Prob. & $\mathbf{R}^{\mathbf{2}}$ \\
\hline $\mathrm{C}$ & 29.7140 & 6.38122 & \multirow{2}{*}{0.0000} & \multirow{2}{*}{0.14336} \\
$\mathrm{X} 2$ & 0.50942 & 4.82314 & & \\
\hline
\end{tabular}

Sumber: Hasil analisis data, diolah (2020)

Nilai $t$ uji $>t$ tabel $(4,823>1,65573)$ dan nilai signifikansinya sebesar 0,0000 , maka $\mathrm{H} 1$ diterima. Terdapat pengaruh positif signifikan kemampuan interpersonal terhadap kesiapan mengelola bisnis. Semakin tinggi kemampuan interpersonal yang dimiliki oleh mahasiswa, maka akan semakin meningkatkan kesiapannya dalam mengelola bisnisnya.

Nilai $R$-square variabel bebas sebesar 0,143 , yang berarti bahwa variabel kemampuan interpersonal (X2) memiliki kemampuan sebesar 14,3 persen dalam mempengaruhi variabel kesiapan dalam mengelola bisnis. Sisanya sebesar 85,7 persen dipengaruhi oleh variabel-variabel lain.

Uji Hipotesis Pengaruh Variabel X1 dan X2 terhadap $Y$

Tabel 4. Hasil Uji Regresi Variabel X1 dan X2 terhadap Y

\begin{tabular}{ccccc}
\hline Var & Coeff & F-Stat & Prob. & $\begin{array}{c}\text { Adj. } \\
\mathbf{R}^{\mathbf{2}}\end{array}$ \\
\hline C & 17.3223 & & & \\
X1 & 0.8005 & 24.0572 & 0.0000 & 0.2477 \\
X2 & 0.2893 & & & \\
\hline
\end{tabular}

Sumber: Hasil analisis data, diolah (2020)

Nilai F Uji > F Tabel $(24,057>3,06)$, maka H1 diterima yang artinya bahwa terdapat pengaruh simultan yang signifikan lokus kendali internal (X1) dan kemampuan interpersonal (X2) terhadap kesiapan mengelola bisnis (Y).

Nilai $R$-square variabel bebas sebesar 0,248 , yang berarti bahwa variabel lokus kendali internal (X1) dan kemampuan interpersonal (X2) memiliki kemampuan sebesar 24,8 persen dalam mempengaruhi variabel kesiapan dalam mengelola bisnis $(\mathrm{Y})$. Sisanya sebesar 75,2 persen dipengaruhi oleh variabel-variabel lain.

\section{Pembahasan}

Berdasarkan hasil analisis deskriptif diketahui bahwa lokus kendali internal yang dimiliki oleh mahasiswa yang memiliki bisnis sebagian besar berada pada kategori sedang. Hasil ini mendukung hasil penelitian Hidayati et al. (2016) dan Ni'mah \& Oktarina (2014), dimana mahasiswa memiliki pola pikir secara lokus kendali internal yang cukup baik. Hasil penelitian ini berbeda dengan hasil penelitian Amanah, et al., (2016) yang menyatakan bahwa mayoritas mahasiswa memiliki skor lokus kendali internal yang tinggi.

Jika dilihat dari masing-masing aspek dalam variabel lokus kendali internal dari Davis dan Phares (1969), yaitu kemampuan, minat, dan usaha, maka aspek minat memiliki nilai mean paling tinggi dibandingkan aspek lainnya. Minat mahasiswa untuk melakukan bisnis sebagai bagian dari variabel lokus kendali internal sudah baik. Hasil tersebut sesuai dengan penelitian Wang \& Wong (2004) dimana para mahasiswa memiliki minat yang tinggi untuk berwirausaha.

Nilai mean aspek usaha juga cukup baik. Mahasiswa bersedia mengerahkan tenaganya untuk berusaha sebaik-baiknya dalam mengelola bisnis yang dimiliki. Usaha yang telah dikerahkan oleh mahasiswa tersebut kemudian menumbuhkan karakteristik khusus yang mampu mengaktivasi perasaan positif yang dapat mengarah secara spesifik dan relevan dengan kegiatan bisnisnya (Breugst, et al., 2012). Selain itu, dengan usaha yang dikerahkan oleh mahasiswa tersebut akan dapat membuatnya menumbuhkan passion dalam berbisnis (Gielnik et al., 2015).

Aspek kemampuan dalam variabel lokus kendali internal merupakan aspek yang memiliki nilai mean paling rendah diantara aspek yang lainnya. Hasil tersebut serupa dengan hasil penelitian Wang \& Wong (2004) yang menunjukkan bahwa kemampuan mahasiswa terkait dengan suatu bidang yang sedang ditekuninya sangat bergantung pada pengetahuan yang dimilikinya. Jika aspek kemampuan mahasiswa dalam hal berbisnis masih belum begitu baik, maka dapat juga dikatakan bahwa pengetahuan berbisnis mahasiswa masih perlu ditambah. 
Hasil analisis deskriptif variabel bebas kedua menunjukkan bahwa kemampuan interpersonal mahasiswa berada pada kategori yang sedang. Hasil ini berbanding terbalik dengan hasil penelitian Firdausi, Hartati, \& Nusantoro (2014) dan Isti'adah (2017) yang memaparkan jika kemampuan komunikasi interpersonal mahasiswa berada pada kategori yang tinggi. Bahkan hasil penelitian dari Oviyanti (2016) menunjukkan bahwa kemampuan komunikasi interpersonal pada mahasiswa berada pada kategori yang sangat tinggi.

Tidak tingginya kemampuan interpersonal pada mahasiswa dalam penelitian ini dapat disebabkan oleh berbagai faktor. Jika dikaitkan dengan aspek-aspek kemampuan interpersonal yang dikemukakan oleh Idrus (2009) yaitu diantaranya kemampuan menyelesaikan konflik dengan orang lain, kemampuan untuk membuka diri, asertif, kemampuan dalam memulai sebuah pembicaraan, kemampuan dalam memberikan dukungan emosional dan empati. Maka pada mahasiswa tentu membutuhkan pengalaman yang lebih banyak lagi dalam berkomunikasi dan bertemu orang lain. Sebab dari keseluruhan aspek tersebut, aspek kemampuan untuk memulai suatu hubungan baru dengan orang lain adalah aspek dengan nilai mean yang paling rendah. Hasil tersebut berbeda dengan penelitian Siska, et al. (2003) yang menyatakan bahwa mahasiswa memiliki kecemasan yang rendah ketika harus memulai untuk berinteraksi dengan orang lain. Dalam hal ini, mahasiswa telah mampu untuk memulai berkomunikasi dengan orang lain.

Aspek dengan nilai mean terendah kedua dan ketiga dari variabel kemampuan interpersonal secara berurutan yaitu aspek asertif dan empati. Hasil tersebut relevan dengan hasil penelitian Idrus (2009), yang menyatakan bahwa ada beberapa aspek kemampuan interpersonal yang belum dapat diterima untuk menjadi kultur di Indonesia, seperti misalnya asertif. Sebab orang yang asertif biasanya akan cenderung terbuka, berani menyatakan pendapat, dan mampu menolak sesuatu yang dapat merugikan dirinya (Khan, 2012). Orang yang kurang asertif sendiri biasanya akan cenderung cemas dalam situasi sosial dan mempunyai harga diri yang cenderung rendah sehingga kesulitan untuk melakukan komunikasi interpersonal (De Vito, 1998). Sedangkan aspek empati menjadi aspek terendah ketiga dari variabel kemampuan interpersonal. Hasil tersebut berbeda dengan hasil penelitian dari Nugroho, Pasiak, \& Tanudjaja (2016), dimana sebagian besar mahasiswa memiliki empati yang tinggi.

Hasil analisis deskriptif pada variabel terikat menunjukkan bahwa kesiapan mengelola bisnis pada mahasiswa berada pada kategori sedang. Hasil ini relevan dengan hasil penelitian yang dilakukan oleh Ratumbuysang \& Rasyid (2015) yang menyatakan bahwa sebagian besar kesiapan mahasiswa dalam berbisnis berada pada kategori cukup. Menurut Hidayati et al. (2016), tidak tingginya kesiapan dalam mengelola bisnis pada mahasiswa disebabkan karena sebagian besar sumber modal bisnis mahasiswa berasal dari dana pribadi. Sedangkan tidak semua mahasiswa memiliki dana pribadi yang memadai sehingga seringkali dana modal bisnis digunakan oleh mahasiswa untuk membiayai keperluan lain. Ketidaksiapan akses modal juga membuat sebagian besar bisnis mahasiswa hanya mampu berkembang di tataran lokal saja. Hasil penelitian ini justru tidak sama dengan hasil penelitian Irsyada, et al. (2018), dan Warsito \& Kartowagiran (2013) yang menyatakan bahwa sebagian besar kesiapan mahasiswa untuk menjalankan bisnis justru berada pada kategori yang tinggi.

Hasil perincian pada masing-masing aspek dalam variabel kesiapan mengelola bisnis, maka aspek pengetahuan dan kesiapan mental adalah dua aspek terendah dalam variabel ini. Hasil tersebut relevan dengan hasil penelitian Wang \& Wong (2004) yang memaparkan bahwa pengetahuan bisnis mahasiswa masih belum memadai. Penelitian Hendrawan \& Sirine (2017) menunjukkan hasil yang berbeda dimana pengetahuan mengenai kewirausahaan dari mahasiswa yang tergolong tinggi. Hasil penelitian Wang \& Wong (2004) juga menyatakan bahwa mahasiswa belum siap secara mental untuk mengambil risiko guna mewujudkan impiannya menjadi pebisnis sukses. Penelitian Murni (2010) justru menunjukkan hasil yang berbeda, dimana kesiapan mental mahasiswa untuk berbisnis berada pada kategori yang tinggi. 
Lokus kendali internal (X1) mempengaruhi kesiapan mengelola bisnis pada mahasiswa (Y). Hasil tersebut mendukung penelitian-penelitian sebelumnya yaitu Endratno dan Widhiandono (2017), Fauzan (2019), Musdalifah dan Baharuddin (2016), Srimulyani (2013), dimana locus of control memiliki pengaruh positif yang signifikan terhadap kesiapan, intensi, maupun niat berwirausaha pada mahasiswa. Karakteristik-karakteristik yang ada pada mahasiswa dengan lokus kendali internal yang baik seperti yang disampaikan oleh Ghufron (2010) yaitu selalu memiliki inisiatif, pantang menyerah untuk menemukan pemecahan masalah, pekerja keras, memiliki tujuan untuk memiliki bisnis yang berhasil, serta kemampuan untuk berpikir efektif akan sangat membantu mahasiswa dalam meningkatkan kesiapannya dalam mengelola bisnis. Hal tersebut sangat berkaitan dengan pendapat Kreitner dan Kinicki (dalam Wiriani et al, 2013), dimana apabila seseorang yang memiliki keyakinan bahwa apapun yang akan terjadi ke depan masih dalam kontrol dirinya, serta individu tersebut bersedia untuk bertanggungjawab atas keputusan yang diambilnya. Secara umum, mahasiswa yang tidak memiliki lokus kendali internal yang baik biasanya cenderung mudah cemas dalam menjalankan bisnis mereka. Hal ini membuat mahasiswa ragu untuk menjalankan bisnis mereka sepenuhnya. Dampaknya adalah bahwa mahasiswa akan dengan mudah dihantui oleh kegagalan atau ketidakberuntungan dalam menjalankan bisnis mereka yang mengarah pada ketidakberlanjutan untuk melanjutkan bisnisnya lagi (Wiriani et al., 2013)

Kemampuan interpersonal mempengaruhi kesiapan mengelola bisnis pada mahasiswa (Y). Hal tersebut membuktikan bahwa keterampilan interpersonal sangat penting untuk membantu mahasiswa dalam menjalankan bisnisnya. Komunikasi interpersonal sendiri didefinisikan oleh Purwanto (2015) sebagai komunikasi yang dilakukan oleh dua orang atau lebih dengan menggunakan bahasa yang saling dipahami dan menggunakan media komunikasi tertentu untuk menggapai tujuan yang telah ditetapkan. Keterampilan interpersonal berkaitan dengan kemampuan mahasiswa untuk melakukan pemasaran produk-produknya, untuk kemudian menawarkannya kepada orang lain. Idrus (2009) menyatakan beberapa komponen pembentuk kemampuan interpersonal adalah kemampuan untuk menyelesaikan konflik dengan orang lain, kemampuan untuk membuka diri, asertif, kemampuan dalam memulai sebuah pembicaraan, kemampuan dalam memberikan dukungan emosional dan empati. Keseluruhan komponen tersebut sangat mendukung individu dalam berwirausaha. Maka dari itu, jika kemampuan interpersonal mahasiswa rendah, maka mahasiswa akan mengalami kesulitan dalam menjual produk-produknya kepada orang lain. Hal ini membuat bisnis sulit berkembang yang membuat mahasiswa akan enggan melanjutkan bisnisnya.

\section{Kesimpulan dan Saran}

\section{Kesimpulan}

Sebagian besar mahasiswa memiliki lokus kendali internal, kemampuan interpersonal, dan kesiapan mengelola bisnis yang berada pada kategori sedang. Terdapat pengaruh positif secara simultan dan signifikan lokus kendali internal (X1) dan kemampuan interpersonal (X2) terhadap kesiapan mengelola bisnis (Y). Terdapat pengaruh positif secara parsial dan signifikan lokus kendali internal (X1) terhadap kesiapan mengelola bisnis (Y). Terdapat pengaruh positif secara parsial dan signifikan antara kemampuan interpersonal (X2) terhadap kesiapan mengelola bisnis (Y).

\section{Saran}

Salah satu keterbatasan dalam penelitian ini yaitu area cakupan sampling yang masih terbatas. Peneliti selanjutnya diharapkan dapat memperluas cakupan dari subjek penelitian agar hasilnya semakin representatif. Penambahan jumlah variabel bebas juga dapat dilakukan agar dapat menemukan prediktor lain yang memiliki kontribusi lebih signifikan dalam mempengaruhi variabel terikat sebab kedua variabel bebas dalam penelitian ini hanya berpengaruh sebanyak 24,8 persen terhadap kesiapan mengelola bisnis. Oleh karena itu, masih ada 75,2 persen variabel bebas lainnya yang diprediksi mampu mempengaruhi variabel kesiapan mengelola 
bisnis. Referensi mengenai variabel bebas dari penelitian lain diantaranya yaitu variabel selfefficacy dan minat berwirausaha pada penelitian Irsyada et al. (2018), variabel lingkungan dan pembelajaran kewirausahaan pada penelitian Ratumbuysang \& Rasyid (2015), variabel sarana pembelajaran praktik, praktik kerja lapangan, dan lingkungan keluarga pada penelitian Warsito \& Kartowagiran (2013). Keseluruhan variabel bebas yang digunakan pada penelitian lain tersebut memiliki kemampuan yang signifikan untuk meningkatkan kesiapan mengelola bisnis pada mahasiswa.

Bagi mahasiswa disarankan untuk terus meningkatkan aspek kemampuan yang dimiliki, khususnya kemampuan yang terkait dengan pengelolaan bisnis. Aspek kemampuan pada variabel lokus kendali internal menjadi kelemahan bagi sebagian besar mahasiswa. Oleh dari itu, dengan semakin meningkatnya kemampuan yang dimiliki oleh mahasiswa, maka diharapkan agar mahasiswa dapat menggunakan cara pandang dengan lokus kendali internal yang semakin baik. Untuk meningkatkan keterampilan membangun relasi interpersonal yang dimiliki, mahasiswa disarankan agar terus berlatih secara intensif, khususnya pada kemampuan untuk memulai suatu hubungan dengan orang lain, perilaku asertif, dan empati. Pengetahuan dan kesiapan mental merupakan aspek-aspek yang paling perlu diperbaiki oleh mahasiswa agar dapat meningkatkan kesiapannya dalam mengelola bisnis. Pengetahuan mengenai bisnis dapat diperoleh dengan mengikuti berbagai macam seminar, pelatihan, dan membaca buku bisnis. Untuk meningkatkan kesiapan mental tentu tidak dapat dilakukan secara instan. Mahasiswa membutuhkan proses yang salah satunya dapat dilakukan dengan menambah jam terbang dalam hal berbisnis, hingga belajar dari kisah sukses dari para pebisnis.

Perguruan tinggi dapat memanfaatkan inkubator bisnis dengan optimal sehingga kesiapan mahasiswa dalam mengelola bisnisnya dapat terus meningkat. Inkubator bisnis dapat berperan sebagai fasilitator untuk memperbaiki aspek-aspek kemampuan yang belum baik pada sebagian besar mahasiswa. Tujuannya agar kesiapan mahasiswa dalam mengelola bisnis semakin meningkat.
Bagi pemerintah, diharapkan dapat terus menyediakan berbagai macam terobosanterobosan agar bisa meningkatkan kesiapan mahasiswa dalam mengelola bisnis. Kompetisi bisnis seperti Program Kreativitas Mahasiswa (PKM), Kompetisi Bisnis Manajemen Indonesia (KBMI), dan Kompetisi Mahasiswa Nasional Bidang Ilmu Bisnis, Manajemen, dan Keuangan (KBMK) perlu terus dilakukan. Kompetisi-kompetisi tersebut akan merangsang mahasiswa agar terus meningkatkan pengetahuan dan kemampuan bisnis. Aspek kemampuan yang masih tergolong rendah membuat lokus kendali internal mahasiswa belum tinggi serta aspek pengetahuan yang juga masih tergolong rendah membuat kesiapan mahasiswa dalam mengelola bisnis juga belum tinggi. Kompetisi-kompetisi bisnis dapat melatih mental mahasiswa pada variabel kesiapan mengelola bisnis agar semakin kuat.

\section{Daftar Referensi}

Adnyana, I., \& Purnami, N. (2016). Pengaruh Pendidikan Kewirausahaan, Self Efficacy dan Locus of Control pada Niat Berwirausaha. E-Jurnal Manajemen Universitas Udayana, 5(2), 1160-1188.

Amanah, E., Rahadian, D., \& Iradianty, A. (2016). Pengaruh Financial Knowledge, Financial Attitude dan External Locus of Control terhadap Personal Financial Management Behavior pada Mahasiswa S1 Universitas Telkom. E-Proceeding of Management, 3(2), 1228-1235.

Barrington, E. (2004). Teaching to Student Diversity in Higher Education: How Multiple Intelligence Theory can Help. Teaching in Higher Education, 9(4), 421-434.

Breugst, N., Domurath, A., Patzelt, H., \& Klaukien, A. (2012). Perceptions of Entrepreneurial Passion and Employees' Commitment to Entrepreneurial Ventures. Entrepreneurship Theory and Practice, 36(1), 171-192.

Crider, A. B. (1983). Psychology. Scott: Foresman \& Company.

Dalyono. (2015). Psikologi Pendidikan. Jakarta: Rineka Cipta.

Davis, \& Phares. (1969). Parental Antecedents 
of Internal-External Control of Reinforcement. Psychological Reports, 24(2), 427-436.

De Vito, J. A. (1998). Messages - Building Interpersonal Communication Skill. New York: Harper and Rav.

Endratno, H., \& Widhiandono, H. (2017). Pengaruh Innovativeness, Kebutuhan akan Prestasi, Locus of Control, Risk Taking Propensity dan Self Confidence Terhadap Intensi Kewirausahaan Mahasiswa Fakultas Ekonomi Universitas Muhammadiyah Purwokerto. Prosiding Seminar Nasional Multi Disiplin Ilmu \& Call For Papers UNISBANK KE-3, 3.

Fauzan. (2019). Pengaruh Soft Skill dan Locus of Control terhadap Kesiapan Fresh Graduate dalam Era Industri 4.0 (Studi Pada prodi Manajemen Unihaz Bengkulu). Creative Research Management Journal, 2(1), 1-10.

Firdausi, A., Hartati, M. T. S., \& Nusantoro, E. (2014). Komunikasi Interpersonal Mahasiswa Bimbingan dan Konseling Universitas Negeri Malang. Journal of Innovative Counseling: Theory, Practice \& Research, 3(2), 31-36.

Ghufron. (2010). Teori-Teori Perkembangan. Bandung: Refika Aditama.

Gielnik, M. M., Spitzmuller, M., Schmitt, A., Klemann, D. K., \& Frese, M. (2015). "I Put in Effort, Therefore I Am Passionate": Investigating the Path from Effort to Passion in Entrepreneurship. Academy of Management Journal, 58(4), 1012-1031.

Guilford, J. P. (1985). Fundamental Statistics in Psychology and Education. Auckland: McGraw-Hill.

Gumay, S. A., \& Seno, A. H. D. (2018). Pengaruh Komunikasi Interpersonal dan Lingkungan Kerja Terhadap Kinerja Karyawan PT. Euro Management Indonesia. Jurnal Administrasi Bisnis, 7(2), $\quad$ 68-77. https://doi.org/10.14710/jab.v7i2.22691

Gunawan, A. W. (2011). Born to be a Genius (Kunci Mengangkat Harta Karun dalam
Diri Anda). Jakarta: PT Gramedia Pustaka Utama.

Handfield, R. (2006). Faith in the Moral Integrity of Others. [online]. Retrieved from

http://www.careersuperstar.com/interpe rsonal_competence/ [diakses 10 Februari 2020]

Hendrawan, J. S., \& Sirine, H. (2017). Pengaruh Sikap Mandiri, Motivasi, Pengetahuan Kewirausahaan terhadap Minat Berwirausaha (Studi Kasus pada Mahasiswa FEB UKSW Konsentrasi Kewirausahaan). AJIE: Asian Journal of Innovation and Entrepreneurship, 2(3), 291-314.

Hidayati, D. R., Setiani, \& Khasan, U. (2016). Penerapan Bisnis Berkelanjutan (Sustainable Business) Mahasiswa Wirausaha di Universitas Trunojoyo Madura. Seminar Nasional Dalam Rangka Dies Natalis Ke 53 Fakultas Pertanian Universitas Sriwijaya Palembang, 40-47. Madura: Fakultas Pertanian Universitas Sriwijaya.

Idrus, M. (2009). Kompetensi Interpersonal Mahasiswa. UNISIA, 32(72).

Iksanudin, M. A. (2012). Pengaruh Komunikasi Interpersonal dan Lingkungan Keluarga terhadap Intensi Berwirausaha Siswa SMK Muhammadiyah 3 Yogyakarta. Universitas Negeri Yogyakarta.

Irsyada, R., Dardiri, A., \& Machmud, R. S. (2018). Kontribusi Minat Berwirausaha dan Self Efficacy terhadap Kesiapan Berwirausaha di Era Revolusi Industri 4.0 Mahasiswa Teknik Informatika seMalang. Jurnal Pendidikan: Teori, Penelitian, Dan Pengembangan, 3(7), 945-954.

Isti'adah, F. N. L. (2017). Profil Komunikasi Interpersonal Mahasiswa. Journal of Innovative Counseling: Theory, Practice \& Research, 1(1), 40-49.

Kartono, K., \& Gulo, D. (2000). Kamus Psikologi. Bandung: Pionir Jaya.

Khan, R. I. (2012). Perilaku Asertif, Harga Diri dan Kecenderungan Depresi. 
Persona, Jurnal Psikologi Indonesia, 1(2), 143-154.

Kholifah, F. N., \& Hadi, N. U. (2017). Analisis Program Magang, Minat Profesi Guru, dan Locus of Control Internal terhadap Kesiapan Menjadi Tenaga Pendidik Mahasiswa Program Studi Pendidikan Ekonomi STKIP PGRI Tulungagung yang Sedang Menempuh Skripsi Tahun 2017/2018. Journal of Management (SME's), 5(2), 205-219.

Levenson, H. (1973). Multidimensional Locus of Control in Psychiatric Patients. Journal of Consulting and Clinical Psychology, 41(3), 397 - 404.

Martin, R. A., \& Lefcourt, H. (1983). Sense of Humor As a Moderator Between Stressors and Moods. Journal of Personality and Social Psychology, 45(6), 1313-1324.

McGaha, V., \& Fitzpatrick, J. (2005). Personal and Social Contributors to Dropout Risk for Undergraduate Students. College Student Journal, 39(2), 287-297.

Murni, I. (2010). Kesiapan Mental Mahasiswa Fakultas Ilmu Pendidikan Universitas Negeri Malang Untuk Berwirausaha. Universitas Negeri Malang.

Musdalifah, \& Baharuddin, A. (2016). Pengaruh Locus of Control dan Sikap Berwirausaha terhadap Intensi Berwirausaha melalui Kreativitas (Studi Kasus pada Ibu Rumah Tangga di Kecamatan Donri-Donri Kabupaten Soppeng). Jurnal Ilmiah Ilmu Administrasi Publik, 5(2), 154-160. https://doi.org/10.26858/jiap.v5i2.1783

Myers, E. G. (1983). Social Psychology. Tokyo: McGraw Hill.

Ni'mah, F. U., \& Oktarina, N. (2014). Pengaruh Minat Profesi Guru, Locus of Control Internal, Peran Guru Pamong dan Prestasi Belajar terhadap Kesiapan Mahasiswa menjadi Guru pada Jurusan Pendidikan Ekonomi Fakultas Ekonomi Universitas Negeri Semarang. Economic Education Analysis Journal, 3(2), 336342.
Nizma, C., \& Siregar, D. A. (2018). Analisis Pengaruh Locus of Control, Need for Achievement dan Risk Taking terhadap Intensi Berwirausaha Alumni Mahasiswa Jurusan Akuntansi Politeknik Negeri Medan. Jurnal Ekonomi Dan Bisnis, 19(1), 30-37.

Nugroho, K. M., Pasiak, T. F., \& Tanudjaja, G. N. (2016). Gambaran Empati pada Mahasiswa Fakultas Kedokteran Universitas Sam Ratulangi Angkatan 2012. Jurnal E-Biomedik (EBm), 4(1).

Oviyanti, F. (2016). Peran Organisasi Kemahasiswaan Intra Kampus dalam Mengembangkan Kecerdasan Interpersonal Mahasiswa. Journal of Islamic Education Management, 2(1), 61-79.

Parsa, K. (2011). A Model of Critical Psychological Factors Influencing Entrepreneurship Development in Iran Small and Medium-Scale. Industries European Journal of Scientific Research, 51(3), 383-395.

Porter, J., Camerlengo., R., DePuye, M., \& Sommer, M. (1999). Campus Life And The Development Of Postsecondary Deaf And Hard Of Hearing Students: Principles And Practices. New York: National Technical Institute for the Deaf Rochester.

Purwanto, D. (2015). Komunikasi Bisnis (5th ed.). Jakarta: Erlangga.

Rahmin, A. (2018). Pengaruh Komunikasi Interpersonal dan Sikap terhadap Keputusan Berwirausaha di Kota Makassar. UIN Alauddin Makassar.

Rahmin, Abdul. (2018). Pengaruh Komunikasi Interpersonal dan Sikap terhadap Keputusan Berwirausaha Di Kota Makassar. UIN Alauddin Makassar.

Rahyubi, H. (2012). Teori-Teori Belajar dan Aplikasi Pembelajaran Motorik. Bandung: Nusa Media.

Ratumbuysang, M. F. N. G., \& Rasyid, A. A. (2015). Peranan Orang Tua, Lingkungan, dan Pembelajaran Kewirausahaan terhadap Kesiapan 
Berwirausaha. Jurnal Pendidikan Vokasi, 5(1), 15-26. https://doi.org/10.21831/jpv.v5i1.6058

Rauch, A., \& Frese, M. (2007). Let's Put the Person Back into Entrepreneurship Research: A Meta-Analysis on the Relationship Between Business Owners' Personality Traits, Business Creation, and Success. European Journal of Work and Organizational Psychology, 16(4), 353-385.

https://doi.org/10.1080/1359432070159 5438

Reiss, M. C., \& Mitra, K. (1998). The Effects of Individual Difference Factors on the Acceptability of Ethical and Unethical Workplace Behaviors. Journal of Business Ethics, 17(14), 1581-1593.

Rosmayanti. (2018). Jack Ma Sebut "Tiga E" dalam Perkembangan Teknologi. [online]. Warta Ekonomi. Retrieved from

https://www.wartaekonomi.co.id/read19 8972/jack-ma-sebut-tiga-edalamperkembangan-teknologi.html/ [Diakses 28 Februari 2020].

Siska, Sudardjo, \& Purnamaningsih, E. H. (2003). Kepercayaan Diri dan Komunikasi Interpersonal pada Mahasiswa. Jurnal Psikologi, 30(2), 6771.

Slameto. (2015). Belajar dan Faktor-Faktor yang Mempengaruhinya. Jakarta: Rineka Cipta.

Soemanto, W. (2012). Psikologi Pendidikan. Jakarta: Rineka Cipta.

Srimulyani, V. A. (2013). Analisis Pengaruh Kecerdasan Adversitas, Internal Locus of Control, Kematangan Karir terhadap Intensi Berwirausaha pada Mahasiswa Bekerja. Widya Warta, 1(2), 96-110.

Susyanti, J., \& Wahyu, A. M. (2019). The Effect of Internal Locus of Control and Interpersonal Ability on The Readiness of Creative Economics Students in Managing their Sustainable Business. The Second International Conference on
Economics, Business and Social Sciences (2nd ICEBUSS). Malang: Fakultas Ekonomi dan Bisnis Universitas Islam Malang.

Tampubolon. (2004). Manajemen Operasional. Jakarta: PT. Ghalia Indonesia.

Wahyu, A. M., Noorrizki, R. D., \& Mantara, A. Y. (2019). Hubungan antara Internal Locus of Control dan Kemampuan Interpersonal terhadap Kesiapan Mahasiswa dalam Mengelola Usahanya secara Berkelanjutan. Seminar Nasional \& Call Paper Psikologi Sosial 2019 Dengan Tema Psikologi Sosial Di Era Revolusi Industri 4.0: Peluang \& Tantangan. Malang: Fakultas Pendidikan Psikologi Universitas Negeri Malang.

Wang, C. K., \& Wong, P.-K. (2004). Entrepreneurial Interest of University Students in Singapore. Technovation, 24(2), 163-172.

Warsito, \& Kartowagiran, B. (2013). Kesiapan Berwirausaha Mahasiswa Akademi Teknologi Kulit Yogyakarta. Jurnal Evaluasi Pendidikan, 1(2), 196207.

Wiriani, W., Piatrini, S. Y., \& Ardana. (2013). Efek Moderasi Locus of Control pada Hubungan Pelatihan dan Kinerja pada Bank Perkreditan Rakyat di Kabupaten Badung. Jurnal Ilmiah Akuntansi Dan Bisnis, 8(2), 99-105.

Yuniati, S. (2017). Pengaruh Praktik Kerja Industri (Prakerin), Keterampilan Interpersonal, Komptensi Kerja terhadap Kesiapan Kerja Siswa SMK PGRI 01 Semarang dengan Efikasi Diri sebagai Variabel Intervening. Universitas Negeri Semarang.

(2016). Jumlah Wirausaha di Indonesia. Jakarta: Badan Pusat Statistik (BPS).

. (2017). Data Statistik dan Hasil Survei Ekonomi Kreatif. Jakarta: Bekraf. 